\title{
Fine root density and root biomass of two Douglas-fir stands on sandy soils in the Netherlands. 1 . Root biomass in early summer
}

\section{A. F. M. OLSTHOORN*}

Department of Forestry, Wageningen Agricultural University, P.O. Box 342, NL 6700 AH Wageningen, Netherlands ( ${ }^{*}$ Present address: 'De Dorschkamp' Research Institute for Forestry and Urban Ecology, P.O. Box 23, NL 6700 AA Wageningen, Netherlands)

Received 16 November 1990; accepted 19 December 1990

\begin{abstract}
In two fully stocked, fast growing Douglas-fir plantations of the Dutch ACIFORN project, detailed studies were carried out on fine root biomass and fine root length to obtain information on fine root densities. For three consecutive years, fine roots were sampled with a root corer in the early part of the growing season. The coarse root biomass was calculated from aboveground stand parameters. The vertical distribution of fine roots in these sites was similar. In the stand with less aboveground biomass the dry weight and density of the fine roots were higher. The fine root biomass agreed with values found in Douglas-fir stands in the Pacific northwest of the USA. Up to $80 \mathrm{~cm}$ depth the fine root biomass varied from $3900 \mathrm{~kg} \mathrm{ha}^{-1}$ in moist conditions to $900 \mathrm{~kg} \mathrm{ha}^{-1}$ after dry periods. The fine root length varied accordingly, with a maximum of $27.10^{6} \mathrm{~m} \mathrm{ha}^{-1}$ and a minimum of $3.10^{6} \mathrm{~m} \mathrm{ha}^{-1}$. The fine root density in the mineral topsoil varied between 0.6 and $0.05 \mathrm{~cm} \mathrm{~cm}^{-3}$; in the subsoil it varied between 0.3 and $0.04 \mathrm{~cm} \mathrm{~cm}^{-3}$. In 1989 there was some sudden root death during a dry period.
\end{abstract}

Keywords: coarse root biomass, fine root biomass, fine root density, fine root length, Pseudotsuga menziesii, shoot:root ratio

\section{Introduction}

In the ACIFORN project (ACIdification of FORests in the Netherlands) growth parameters and the main factors influencing growth were monitored in detail in two Douglas-fir stands in the central part of the Netherlands for several years, to study the impact of air pollution on forest growth (Evers et al., 1987). Fine root density was assessed because it is one of the stand characteristics linking soil hydrology and soil chemistry to forest growth. Furthermore, the growth and mortality of fine roots account for a significant part of the carbon balance of the entire stand. The main emphasis was on fine roots (roots with a diameter of less than $2 \mathrm{~mm}$, including all root tips) because they control the tree's capacity to take up water and nutrients, and constitute the main interface with the soil solution. Mycorrhizal fungi are part of this interface, but were not studied separately. This paper presents data on fine 
root density, root biomass, and elementary root morphology. The data on fine roots were collected in the field in three consecutive years $(1987,1988$, and 1989). Coarse root biomass (roots with a diameter of more than $2 \mathrm{~mm}$, excluding all root tips) was estimated from aboveground stand parameters according to Santantonio et al. (1977) using an allometric relation between diameter breast height of the stem and coarse root dry weight that Kuiper \& Coutts (1991) established for Douglas-fir in the Netherlands.

To collect basic information on the fine root density and fine root biomass (dry matter), a root sampling programme was carried out in the first half of the growing season in the three consecutive years. In 1989 a dry period preceded the sampling. The effect of this dry period on root density will be described. The survey of fine roots was intended to provide estimates per plot or stand, because fine roots cannot be attributed to a single tree (McMinn, 1963; Kuiper \& Coutts, 1991).

In a second paper (Olsthoorn \& Tiktak, 1991) data will be presented to show how the periodicity of fine root growth depends on weather conditions and soil moisture, and the total carbon allocation to the root system is estimated.

\section{Site description}

The two ACIFORN stands were planted on clearcut areas with a coastal provenance of Douglas-fir (Pseudotsuga menziesii (Mirb.) Franco), and are located $10 \mathrm{~km}$ apart in the 'Veluwe' area in the Netherlands (Figure 1). The stands are

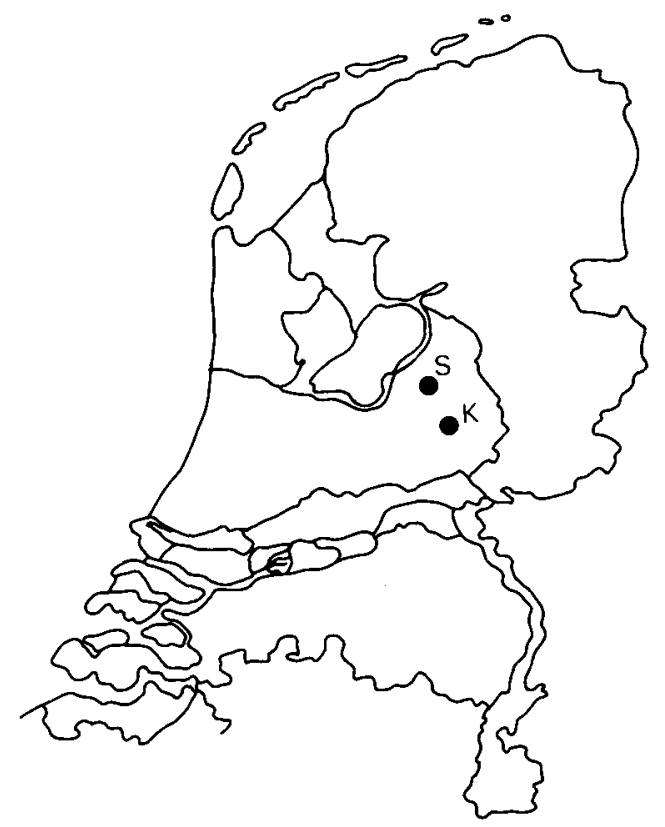

Fig. 1. Location of the two ACIFORN Douglas-fir stands in the Netherlands: $K=$ Kootwijk and $\mathbf{S}=$ Speuld. 
even-aged and have been repeatedly thinned. They were last thinned more than three years before the ACIFORN project started; at the time of sampling the canopy was completely closed. There was no ground vegetation, hence all living roots were assumed to be Douglas-fir.

The soils in both stands are sandy and well drained. The water table is very deep and the soil contains very little gravel. One of the stands (Kootwijk, 52 $11^{\prime} \mathrm{N}$, $5^{\circ} 46^{\prime} \mathrm{E}$ ) is located on eolian sands which have been farmed in previous ages before forest stands were established. The soil is horizontally homogeneous, and consists of a Leptic podzol (FAO/UNESCO, 1974). The Ap is $40 \mathrm{~cm}$ thick. The C horizon starts at $90 \mathrm{~cm}$ depth. The $\mathrm{pH}-\mathrm{KCl}$ of the thin and discontinuous humus layer in the organic horizon is 2.9 ; the $\mathrm{pH}-\mathrm{KCl}$ at $80 \mathrm{~cm}$ depth is 4.6 . The other stand (Speuld, $\left.52^{\circ} 15^{\prime} \mathrm{N}, 5^{\circ} 41^{\prime} \mathrm{E}\right)$ is located on preglacial sand deposits, which are very heterogeneous, especially in the subsoil below $40 \mathrm{~cm}$ depth. The soil profile consists of an Orthic podzol or Luvisol (FAO/UNESCO, 1974). The A horizon is very thin $(7 \mathrm{~cm})$ and the $\mathrm{C}$ horizon starts at $60 \mathrm{~cm}$ depth. The $\mathrm{pH}-\mathrm{KCl}$ in the thin and discontinuous humus layer of the organic horizon is 3.1 ; the $\mathrm{pH}-\mathrm{KCl}$ at $80 \mathrm{~cm}$ depth is 4.3 . The Speuld soil contains more loam than the Kootwijk soil. A detailed soil survey was done to identify the area with the most homogeneous soil, and the root sampling was done in that area. The soil surface is level in both stands.

The stand descriptions are presented in Table 1a. Tree age and number of trees per hectare are similar. In Table $1 \mathrm{~b}$ the basal area increment and stem volume increment is presented for 1987,1988 and 1989. In Kootwijk the productivity is lower than in Speuld. In each stand a single small subplot of $10 \times 11 \mathrm{~m}$ was established to sample fine roots.

Table 1. Stand description (a) of the subplots used for root measurements in both ACIFORN plots in forestry districts Kootwijk and Speuld and stand growth (b) in 1987, 1988 and 1989.

a. Stand description (per January 1 1987)

Tree age

Stems per hectare

Average height of dominant trees

Diameter of tree with mean basal area $\left(d_{\mathrm{g}}\right)$

b. Stand growth

Basal area, current annual increment:

1987

1988

1989

Volume, current annual increment:

$1987^{1}$

1988

1989

\section{Kootwijk}

36 years

992

$19.0 \mathrm{~m}$

$18.7 \mathrm{~cm}$

\section{Speuld}

28 years

886

$20.3 \mathrm{~m}$

$21.3 \mathrm{~cm}$

1 Tree heights were not measured at the beginning of 1987. The height/diameter relation of the winter ' $87 / 288$ was used to calculate stem volumes for that period. Therefore the volume increment in 1987 for both Kootwijk en Speuld may have been underestimated. 


\section{Methods}

In 1987,1988 and 1989 a root corer sampling programme was used to assess the root density at different depths, the spatial variability of fine root density and the fine root biomass. In Kootwijk, the samples were taken from 6 to 13 July in 1987, and again on 26 May in 1988 and 18 June in 1989. In Speuld, samples were taken from 15 June to 3 July in 1987,16 to 20 May in 1988 and also 13 to 15 June in 1989. In 1987, 37 sampling points per plot were chosen in Kootwijk and 55 in Speuld, to find the statistically acceptable minimum numbers of samples for the subsequent years. In Speuld a second plot (henceforth referred to as Speuld West) was selected in 1988 on a more sandy part of the stand to take account for the spatial variability of the soil. In 1988 and 1989 , only 12 sampling points were chosen per plot. They were distributed systematically in the plots and were at different distances from the tree stems, because the trees are spaced irregularly. It was assumed that the spatial variability of the fine root density is independent of distance from the three (Reynolds, 1970; Kummerow et al., 1990).

The root corer used in the study was designed by Goedewaagen (Böhm, 1979). It is a cylindrical soil coring sampling tube, $8 \mathrm{~cm}$ in diameter and $15 \mathrm{~cm}$ long and has a sharp serrated edge to cut small roots. It was driven into the soil with a $2 \mathrm{~kg} \mathrm{ham}$ mer. The sample was divided into different subsamples if it was necessary to account for different soil horizons. The soil was sampled to a depth of $80 \mathrm{~cm}$. The roots below $80 \mathrm{~cm}$ depth were not sampled. Samples were stored in a freezer at $-20^{\circ} \mathrm{C}$ until processing.

Before measuring root length and root biomass the sand and loam were washed off the roots with tap water above a $2 \mathrm{~mm}$ mesh sieve. Only living roots were taken into account. They were separated by hand from organic matter and dead roots, on the basis of colour, brittleness, structure of cortex or bark and colour of stele or xylem, as described by Santantonio \& Hermann (1985) and Vogt et al. (1981 and 1983). It was assumed that it is possible to recognize dead roots in a corer sample one week after their death. The total length of living fine roots was estimated using the line intersect method (Tennant, 1975). Intersections were counted by eye on fresh samples. Finally, the roots were oven-dried at $70^{\circ} \mathrm{C}$ for at least 16 hours to determine the dry weight (biomass) of the samples. The data presented on fine root dry weight have not been corrected for the weight of soil particles that might still be attached to the roots. The values for each sampling point were recalculated to $10 \mathrm{~cm}$ intervals so that the averages and standard deviations could be calculated for each $10 \mathrm{~cm}$ soil layer.

In the 1988 sampling the fine roots in the organic horizon were not determined separately, but were added to the first sample in the mineral soil. They were subsequently estimated, on the assumption that the relation between the amount of fine roots in the organic horizon in 1988 and the total amount up to $80 \mathrm{~cm}$ depth was the same as in 1987.

When processing the roots from the 1989 sampling, an attempt was made to distinguish roots that had recently died from those that already had died before the dry period, so that the fine root densities before the dry period could be estimated. 
However, this could not be done with great accuracy.

Coarse root biomass was not measured directly in the ACIFORN research sites. It was estimated from aboveground stem diameters, using allometric equations from Santantonio et al. (1977) and Kuiper \& Coutts (1991). Kuiper \& Coutts (1991) established the relation

$$
W_{\mathrm{cr}}=0.01 d^{2.63}
$$

between dry weight of the coarse roots $\left(W_{\mathrm{cr}}\right.$, in $\left.\mathrm{kg}\right)$ and tree diameter $(d$, in $\mathrm{cm})$ at breast height $(1.30 \mathrm{~m})$ for Douglas-fir of similar ages and comparable sites in the Netherlands with a correlation coefficient $\left(r^{2}\right)$ of 0.96 .

\section{Results}

\section{Number of sampling points}

The average fine root length up to $80 \mathrm{~cm}$ depth in Kootwijk in 1987, was $25.10^{6}$ $\mathrm{m} \mathrm{ha}^{-1}$ with a $95 \%$ confidence interval ranging from $22.10^{6}$ to $28.10^{6} \mathrm{~m} \mathrm{ha}^{-1}$, based on 37 sampling points. In Speuld the average was $19.10^{6} \mathrm{~m} \mathrm{ha}^{-1}$ with a $95 \%$ confidence interval ranging from $17.10^{6}$ to $21.10^{6} \mathrm{~m} \mathrm{ha}^{-1}$, based on 55 sampling points.

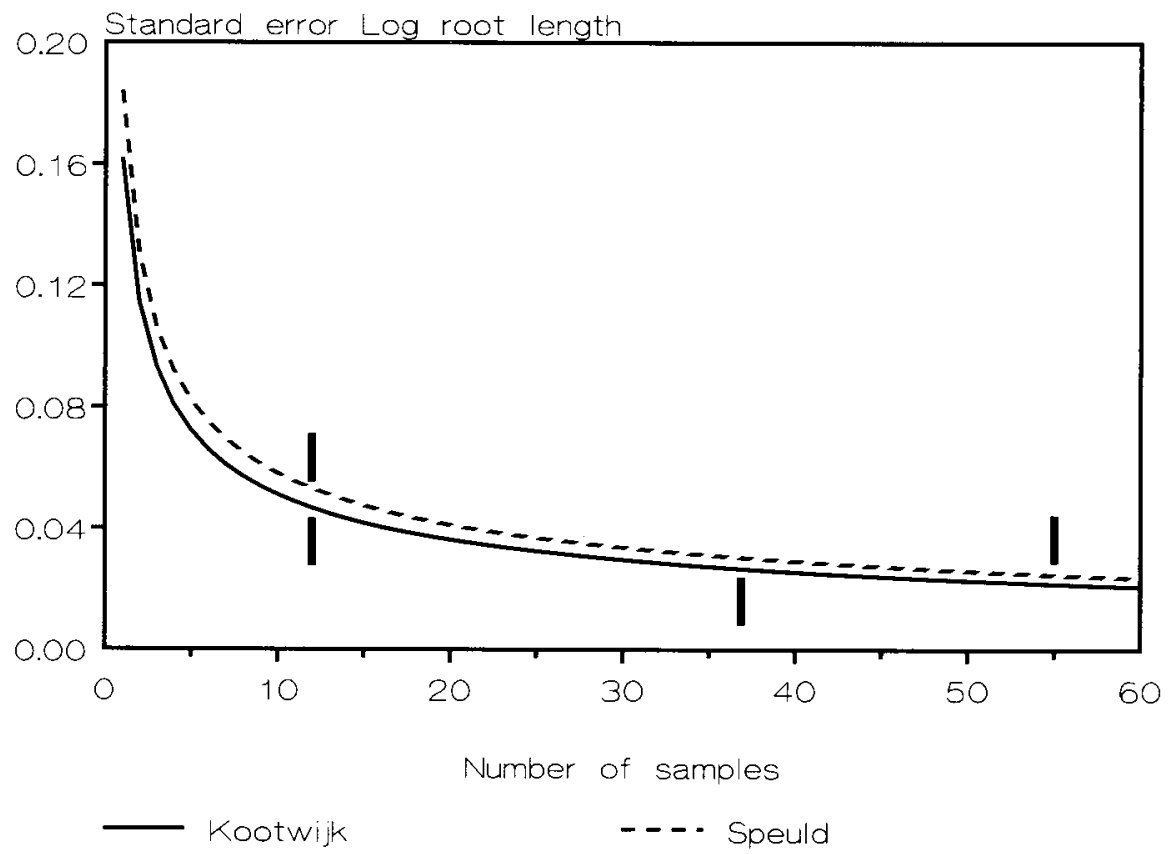

Fig. 2. Estimated standard error in relation to number of sampling points. Standard error was calculated from data on total fine root length per hectare from each sampling point after logarithmic transformation. Bars on the right indicate the number of sampling points in 1987 for both sites. Bars on the left indicate number of sampling points in each subplot in 1988 and 1989. 


\section{A. F. M. OLSTHOORN}

Figure 2 shows the standard error of the mean at different numbers of sampling points for logarithmically transformed data on total fine root length up to $80 \mathrm{~cm}$ depth from both Kootwijk and Speuld. Below 10 samples the standard error increases fairly sharply. Therefore, in 1988 and 198912 sampling points per subplot were considered to present reliable data on the distribution of fine root biomass and fine root density in the soil profile. The estimated $95 \%$ confidence interval for 12 sampling points in 1987 ranged from $20.10^{6}$ to $31.10^{6} \mathrm{~m} \mathrm{ha}^{-1}$ in Kootwijk and from $15.10^{6}$ to $24.10^{6} \mathrm{~m} \mathrm{ha}^{-1}$ in Speuld.

\section{Fine roots}

The results of the root corer sampling programme in both ACIFORN stands in 1987, 1988 and 1989 are presented in Tables 2 and 3, up to a depth of $80 \mathrm{~cm}$, for each $10 \mathrm{~cm}$ soil layer. The vertical root length distribution of both sites up to $80 \mathrm{~cm}$ depth was similar in all years. The results for 1987 and 1988 were almost identical. The total fine root biomass in Kootwijk was $3900 \mathrm{~kg} \mathrm{ha}^{-1}$ in 1987 and $4300 \mathrm{~kg} \mathrm{ha}^{-1}$ in 1988. The corresponding figures for Speuld East were 2800 and $3200 \mathrm{~kg} \mathrm{ha}^{-1}$, respectively. In the second subplot in Speuld (Speuld West) there were nearly 2800 $\mathrm{kg} \mathrm{ha}^{-1}$ fine roots in 1988; the differences between Kootwijk and Speuld West were somewhat greater than those between Kootwijk and Speuld East. Both subplots have to be used in a 1:1 ratio to calculate stand averages for Speuld.

The fine root density in Kootwijk in the top $40 \mathrm{~cm}$ of the mineral soil ranged from 0.3 to $0.7 \mathrm{~cm} \mathrm{~cm}^{-3}$ in both 1987 and 1988 . At $40 \mathrm{~cm}$ depth the fine root density was about $0.3 \mathrm{~cm} \mathrm{~cm}^{-3}$ and decreased to nearly zero at $80 \mathrm{~cm}$ depth. The total thickness of the organic horizon in both stands was $4 \mathrm{~cm}$. Based on the assumption that the fine roots in the bottom part of the organic horizon were confined to a layer $2 \mathrm{~cm}$ thick, the fine root density in Kootwijk was nearly $2 \mathrm{~cm} \mathrm{~cm}^{-3}$ in both 1987 and 1988 . The specific root length (SRL) of the fine roots in Kootwijk was around $10 \mathrm{~m} \mathrm{~g}^{-1}$ in the organic horizon and decreased to 3 or $4 \mathrm{~m} \mathrm{~g}^{-1}$ at $80 \mathrm{~cm}$ depth with a steep decline at $40 \mathrm{~cm}$ depth where the bottom of the Ap horizon is located.

In Speuld the fine root density was somewhat lower than in Kootwijk. In the top $40 \mathrm{~cm}$ of the mineral soil in Speuld it ranged from 0.2 to $0.5 \mathrm{~cm} \mathrm{~cm}^{-3}$ in 1987 and 1988. Below $40 \mathrm{~cm}$ depth it ranged from 0.1 to $0.2 \mathrm{~cm} \mathrm{~cm}^{-3}$. The fine roots in Speuld extended further down in the soil profile. Using the same assumptions as for Kootwijk, the fine root density in the bottom $2 \mathrm{~cm}$ of the organic horizon in Speuld was less than $1.4 \mathrm{~cm} \mathrm{~cm}^{-3}$ in 1987 and 1988. The SRL in Speuld was greater than in Kootwijk in the whole soil profile in 1987 and 1988 and the decline of the SRL with increasing depth was more gradual.

In June 1989, root densities and fine root dry weights were very small at both sites, because of a dry period in May (see also Olsthoorn \& Tiktak, 1991). In both Kootwijk and Speuld the fine root biomass was one-third to one-quarter that of the two previous years. The decrease in fine root density was even more pronounced because the average SRL in 1989 was a third less than in the two preceding years. In both plots, the fine root density in the upper $40 \mathrm{~cm}$ of the mineral soil ranged from 0.03 to $0.1 \mathrm{~cm} \mathrm{~cm}^{-3}$; below $40 \mathrm{~cm}$ depth it ranged from $0.03 \mathrm{~cm} \mathrm{~cm}^{-3}$ to zero. In the 
bottom part of the organic horizon the fine root density was less than $0.4 \mathrm{~cm} \mathrm{~cm} 3$ in 1989 in both Kootwijk and Speuld. In 1989 the SRL was much smaller in both Kootwijk and Speuld. During a dry period the thicker fraction of the fine roots appear to have a greater chance of surviving, hence the smaller value of the SRL.

In Table 3, the coefficients of variation of fine root biomass, fine root density and SRL for both sites and in all three years are presented. The coefficients of variation increased as the amount of fine roots decreased, as can be seen at greater depth in the soil profile and in the results of the 1989 sampling. The standard deviations in Speuld were larger than in Kootwijk, reflecting soil heterogeneity. For each $10 \mathrm{~cm}$ layer the standard deviations were larger than the standard deviation of the totals up to $80 \mathrm{~cm}$ depth. In 1987 at both sites, the total fine root length per sampling point $\left(50 \mathrm{~cm}^{2}\right.$ soil surface) varied between $2 \mathrm{~m}$ and $40 \mathrm{~m}$ (average around $10 \mathrm{~m}$ ). High root densities were found in old decayed coarse roots from the previous forest stand (see also van Noordwijk et al., 1991).

\section{Coarse roots}

The estimates of the coarse root biomass presented in Table 4 are based on diameter at breast height of a tree with a mean basal area $\left(d_{\mathrm{g}}\right.$, see Table 1$)$. The coarse root biomass was estimated for four winter periods. The growth could thus be estimated for three growing seasons. Coarse root biomass gradually accumulated over the years, because stem diameters increased; the stands were not thinned in that period. The turnover of coarse roots was assumed to be accounted for by the use of an allometric relationship. Since the stem growth did not fluctuate much over the three years, the estimated growth of coarse roots was nearly constant. In Kootwijk the total amount of coarse roots, and their growth was less than in Speuld, as could be expected from the data on aboveground growth of the stand.

\section{Discussion}

The fine root densities in these two Douglas-fir stands on sandy soils in the Netherlands are low compared to agricultural crops (de Willigen \& van Noordwijk, 1987): the maximum was $0.7 \mathrm{~cm} \mathrm{~cm}^{-3}$ in the topsoil in 1987 and 1988 and the minimum was $0.08 \mathrm{~cm} \mathrm{~cm}^{-3}$ following the dry period in 1989 (Table 2). The roots with a diameter between 2 and $5 \mathrm{~mm}$ were not determined in this study but might also contribute to uptake of water and nutrients. However, according to Eis (1987) the roots in this fraction only add around $2 \%$ to the total length of Douglas-fir roots that are less than $2 \mathrm{~mm}$ in diameter. This is well within the range of variation of the data presented in this paper. The coefficients of variation of fine root densities and fine root biomass (Table 3) are in the same order of magnitude as van Noordwijk et al. (1985) have found for grassland.

The data on fine root biomass for Douglas-fir stands in the Pacific northwest of North America are in agreement with these data. Instead of dry weight alone, length and densities of fine roots better express the potential to take up water and nutrients (de Willigen \& van Noordwijk, 1987). Assuming an SRL of $10 \mathrm{~m} \mathrm{~g}^{-1}$ dry 


\section{A. F. M. OLSTHOORN}

Table 2. Average fine root biomass (dry weight) per hectare, fine root density and specific root length (SRL) in all subplots of the ACIFORN sites in $10 \mathrm{~cm}$ layers $(\mathrm{H}=$ humus layer of the organic horizon) in three consecutive years.

\begin{tabular}{|c|c|c|c|c|c|c|c|c|c|}
\hline $\begin{array}{l}\text { Depth } \\
\text { (cm) }\end{array}$ & $\begin{array}{l}\text { Biomass } \\
\left(\mathrm{kg}^{-1}\right) \\
\left.\mathrm{ha}^{-1}\right)\end{array}$ & $\begin{array}{l}\text { Density } \\
\left(\mathrm{cm}^{-3}\right) \\
\left.\mathrm{cm}^{-3}\right)\end{array}$ & $\begin{array}{l}\text { SRL } \\
\left(\mathrm{m} \mathrm{g}^{-1}\right)\end{array}$ & $\begin{array}{l}\text { Biomass } \\
\left(\mathrm{kg}^{-1}\right) \\
\left.\mathrm{ha}^{-1}\right)\end{array}$ & $\begin{array}{l}\text { Density } \\
(\mathrm{cm} \\
\left.\mathrm{cm}^{-3}\right)\end{array}$ & $\begin{array}{l}\mathrm{SRL} \\
\left(\mathrm{m} \mathrm{g}^{-1}\right)\end{array}$ & $\begin{array}{l}\text { Biomass } \\
(\mathrm{kg} \\
\left.\mathrm{ha}^{-1}\right)\end{array}$ & $\begin{array}{l}\text { Density } \\
\left(\mathrm{cm}^{-3}\right) \\
\left.\mathrm{cm}^{-3}\right)\end{array}$ & $\begin{array}{l}\mathrm{SRL} \\
\left(\mathrm{m} \mathrm{g}^{-1}\right)\end{array}$ \\
\hline Kootwijk & \multicolumn{3}{|l|}{1987} & \multicolumn{3}{|l|}{1988} & \multicolumn{3}{|l|}{1989} \\
\hline $\mathrm{H}$ & 322 & 1.87 & 11.64 & 379 & 1.97 & 10.40 & 145 & 0.37 & 5.13 \\
\hline $0-10$ & 813 & 0.74 & 9.12 & 691 & 0.55 & 8.01 & 114 & 0.06 & 5.42 \\
\hline $10-20$ & 674 & 0.54 & 8.08 & 710 & 0.51 & 7.23 & 170 & 0.05 & 3.23 \\
\hline $20-30$ & 661 & 0.41 & 6.17 & 691 & 0.43 & 6.24 & 257 & 0.06 & 2.19 \\
\hline $30-40$ & 575 & 0.26 & 4.53 & 615 & 0.34 & 5.53 & 187 & 0.03 & 1.64 \\
\hline $40-50$ & 463 & 0.20 & 4.37 & 656 & 0.24 & 3.73 & 63 & 0.02 & 3.08 \\
\hline $50-60$ & 291 & 0.12 & 4.20 & 390 & 0.12 & 3.03 & 92 & 0.02 & 2.36 \\
\hline $60-70$ & 110 & 0.04 & 3.57 & 126 & 0.04 & 2.88 & 28 & 0.007 & 2.39 \\
\hline $70-80$ & 35 & 0.01 & 3.98 & 70 & 0.02 & 3.00 & 10 & 0.003 & 3.23 \\
\hline Total & 3944 & & & 4327 & & & 1066 & & \\
\hline \multicolumn{3}{|c|}{ Arithmetical average } & 6.19 & & & 5.56 & & & 3.18 \\
\hline \multicolumn{4}{|c|}{ Speuld East 1987} & \multicolumn{3}{|l|}{1988} & \multicolumn{3}{|l|}{1989} \\
\hline H & 186 & 1.01 & 10.86 & 215 & 1.34 & 12.48 & 90 & 0.34 & 7.56 \\
\hline $0-10$ & 582 & 0.55 & 9.46 & 510 & 0.45 & 8.83 & 190 & 0.09 & 4.52 \\
\hline $10-20$ & 535 & 0.45 & 8.36 & 496 & 0.37 & 7.53 & 136 & 0.06 & 4.43 \\
\hline $20-30$ & 432 & 0.32 & 7.43 & 552 & 0.37 & 6.79 & 289 & 0.07 & 2.58 \\
\hline $30-40$ & 292 & 0.18 & 6.00 & 410 & 0.27 & 6.67 & 115 & 0.03 & 2.57 \\
\hline $40-50$ & 250 & 0.14 & 5.62 & 366 & 0.20 & 5.35 & 44 & 0.02 & 5.07 \\
\hline $50-60$ & 205 & 0.11 & 5.38 & 239 & 0.13 & 5.25 & 38 & 0.01 & 3.00 \\
\hline $60-70$ & 149 & 0.07 & 4.77 & 203 & 0.11 & 5.60 & 26 & 0.006 & 2.36 \\
\hline $70-80$ & 139 & 0.06 & 4.26 & 228 & 0.10 & 4.27 & 1 & 0.001 & 5.00 \\
\hline Total & 2769 & & & 3219 & & & 929 & & \\
\hline \multicolumn{2}{|c|}{ Arithmetical average } & & 6.90 & & & 6.97 & & & 4.12 \\
\hline \multicolumn{2}{|c|}{ Speuld West } & & & \multicolumn{3}{|l|}{1988} & \multicolumn{3}{|l|}{1989} \\
\hline $\mathbf{H}$ & & & & 185 & 1.06 & 11.44 & 85 & 0.26 & 5.98 \\
\hline $0-10$ & & & & 389 & 0.33 & 8.36 & 201 & 0.12 & 5.81 \\
\hline $10-20$ & & & & 576 & 0.45 & 7.74 & 179 & 0.07 & 3.89 \\
\hline $20-30$ & & & & 439 & 0.35 & 7.96 & 266 & 0.08 & 3.10 \\
\hline $30-40$ & & & & 296 & 0.20 & 6.65 & 131 & 0.04 & 3.24 \\
\hline $40-50$ & & & & 183 & 0.11 & 5.78 & 87 & 0.02 & 2.79 \\
\hline $50-60$ & & & & 218 & 0.09 & 4.26 & 84 & 0.02 & 2.33 \\
\hline $60-70$ & & & & 236 & 0.09 & 3.75 & 18 & 0.01 & 4.30 \\
\hline $70-80$ & & & & 237 & 0.09 & 3.73 & 0 & 0.00 & \\
\hline Total & & & & 2759 & & & 1051 & & \\
\hline \multicolumn{4}{|c|}{ Arithmetical average } & & & 6.63 & & & 3.93 \\
\hline
\end{tabular}


Table 3. Coefficient of variation as percentage of average fine root biomass (dry weight) per hectare, fine root density and specific root length (SRL) in all subplots of the ACIFORN sites in $10 \mathrm{~cm}$ layers (H $=$ humus layer of the organic horizon) in three consecutive years. The coefficients of variation were calculated after logarithmically transforming of the data to correct for skewed frequency distribution of the fine root parameters.

\begin{tabular}{lllllllll}
\hline $\begin{array}{l}\text { Depth } \\
(\mathrm{cm})\end{array}$ & Biomass & $\begin{array}{l}\text { Density } \\
(\%)\end{array}$ & $\begin{array}{l}\text { SRL } \\
(\%)\end{array}$ & $\begin{array}{l}\text { Biomass } \\
(\%)\end{array}$ & $\begin{array}{l}\text { Density } \\
(\%)\end{array}$ & $\begin{array}{l}\text { SRL } \\
(\%)\end{array}$ & $\begin{array}{l}\text { Biomass Density } \\
(\%)\end{array}$ & $\begin{array}{l}\text { SRL } \\
(\%)\end{array}$ \\
\hline$\%)$ & $(\%)$
\end{tabular}

Kootwijk 1987

$\begin{array}{rrrr}\mathrm{H} & 81 & 84 & 38 \\ 0-10 & 44 & 48 & 27 \\ 10-20 & 41 & 48 & 26 \\ 20-30 & 55 & 59 & 32 \\ 30-40 & 80 & 89 & 39 \\ 40-50 & 67 & 75 & 42 \\ 50-60 & 82 & 109 & 52 \\ 60-70 & 142 & 111 & 137 \\ 70-80 & 176 & 161 & 137\end{array}$

\begin{tabular}{rrrrrrr}
1988 & & & & & 1989 & \\
\cline { 1 - 3 } \cline { 5 - 6 } 41 & 42 & 27 & & 113 & 126 & 119 \\
54 & 48 & 25 & & 116 & 87 & 58 \\
73 & 58 & 23 & & 105 & 98 & 61 \\
68 & 61 & 22 & & 101 & 100 & 88 \\
56 & 57 & 30 & & 130 & 93 & 95 \\
87 & 48 & 27 & & 109 & 118 & 91 \\
111 & 73 & 49 & & 170 & 136 & 146 \\
129 & 99 & 77 & & 225 & 204 & 158 \\
194 & 186 & 113 & 330 & 304 & 277
\end{tabular}

Total 38

40

62

Arithmetical average

22

17

30

Speuld East 1987

$\begin{array}{rrrr}\mathbf{H} & 103 & 100 & 42 \\ 0-10 & 64 & 57 & 31 \\ 10-20 & 63 & 52 & 33 \\ 20-30 & 70 & 66 & 72 \\ 30-40 & 81 & 64 & 42 \\ 40-50 & 86 & 75 & 41 \\ 50-60 & 104 & 121 & 64 \\ 60-70 & 128 & 133 & 77 \\ 70-80 & 197 & 166 & 101\end{array}$

Total $\quad 54$

Arithmetical average

26

Speuld West

$\mathbf{H}$
$0-10$
$10-20$
$20-30$
$30-40$
$40-50$
$50-60$
$60-70$
$70-80$

Total

\begin{tabular}{|c|c|c|c|c|c|}
\hline \multicolumn{3}{|c|}{1988} & \multicolumn{3}{|c|}{1989} \\
\hline 52 & 58 & 29 & 118 & 145 & 107 \\
\hline 72 & 71 & 43 & 117 & 107 & 118 \\
\hline 46 & 54 & 23 & 112 & 184 & 109 \\
\hline 63 & 65 & 23 & 149 & 210 & 151 \\
\hline 87 & 81 & 27 & 221 & 254 & 155 \\
\hline 102 & 97 & 36 & 272 & 223 & 134 \\
\hline 84 & 100 & 57 & 189 & 137 & 178 \\
\hline 89 & 108 & 54 & 200 & 167 & 127 \\
\hline 203 & 162 & 59 & 200 & 292 & 279 \\
\hline 52 & & & 103 & & \\
\hline
\end{tabular}

16

71

\begin{tabular}{|c|c|c|c|c|c|}
\hline \multicolumn{3}{|c|}{1988} & \multicolumn{3}{|c|}{1989} \\
\hline 51 & 69 & 26 & 169 & 115 & 126 \\
\hline 97 & 123 & 42 & 111 & 91 & 58 \\
\hline 79 & 87 & 55 & 84 & 104 & 66 \\
\hline 65 & 55 & 28 & 114 & 101 & 74 \\
\hline 81 & 84 & 41 & 83 & 130 & 102 \\
\hline 98 & 92 & 45 & 116 & 113 & 101 \\
\hline 179 & 128 & 72 & 188 & 161 & 124 \\
\hline 208 & 166 & 75 & 176 & 195 & 131 \\
\hline 261 & 187 & 92 & - & - & - \\
\hline \multirow[t]{2}{*}{69} & & & 70 & & \\
\hline & & 21 & & & 42 \\
\hline
\end{tabular}

Netherlands Journal of Agricultural Science 39 (1991) 


\section{A. F. M. OLSTHOORN}

Table 4. Estimation of dry weight of coarse roots $\left(W_{\mathrm{cr}}\right.$, roots $>2 \mathrm{~mm}$ diameter $)$ per tree and per hectare via diameter breast height of a tree of mean basal area $\left(d_{\mathrm{g}}\right)$. In formula: $W_{\mathrm{cr}}=0.01 d_{\mathrm{g}}^{2.63}$, with $r^{2}=$ 0.96, from Kuiper \& Coutts, 1991.

\begin{tabular}{llllll}
\hline Site & Year & $\begin{array}{l}d_{\mathrm{g}} \\
(\mathrm{cm})\end{array}$ & $\begin{array}{l}W_{\mathrm{cr}} \text { tree }^{-1} \\
\left(\mathrm{~kg} \mathrm{tree}^{-1}\right)\end{array}$ & $\begin{array}{l}W_{\mathrm{cr}} \mathrm{ha}^{-1} \\
\left.\text { tons ha }^{-1}\right)\end{array}$ & $\begin{array}{l}\text { growth of } W_{\mathrm{cr}} \\
\left(\text { tons ha }^{-1} \mathrm{yr}^{-1}\right)\end{array}$ \\
Kootwijk $^{2}$ & $86 / 87$ & 18.7 & 24 & 23.8 & \\
& $87 / 88$ & 19.2 & 25 & 24.8 & 1.0 \\
& $88 / 89$ & 19.7 & 27 & 26.8 & 2.0 \\
& $89 / 90$ & 20.3 & 29 & 28.8 & 2.0 \\
Speuld $^{3}$ & & & & & \\
& $86 / 87$ & 21.3 & 32 & 28.4 & 2.6 \\
& $87 / 88$ & 22.1 & 35 & 31.0 & 2.7 \\
& $88 / 89$ & 22.8 & 38 & 33.7 & 2.6 \\
\hline
\end{tabular}

${ }^{1}$ Stem diameter measurement in winter season.

2992 trees ha ${ }^{-1}$.

3886 trees ha $^{-1}$.

matter, the fine root length in these North-American studies varies from $20.10^{6} \mathrm{~m}$ $\mathrm{ha}^{-1}$ to $60.10^{6} \mathrm{~m} \mathrm{ha}^{-1}$ in the whole rooted profile (Santantonio \& Hermann, 1985; Eis, 1987; Vogt et al., 1983). Vogt et al. (1983) recorded some smaller values in October: from $2.10^{6} \mathrm{~m} \mathrm{ha} \mathrm{h}^{-1}$ in very productive sites to $35.10^{6} \mathrm{~m} \mathrm{ha}^{-1}$ in poorly productive sites. Bowen (1985) found that the values of fine root densities of trees in general are much smaller than those of grasses or cereals; the greatest fine root densities he recorded for trees in the topsoil were $3 \mathrm{~cm} \mathrm{~cm}^{-3}$ for Pinus radiata and 5 $\mathrm{cm} \mathrm{cm}^{-3}$ for Pinus sylvestris.

After a dry period the SRL is almost halved, showing that the finest roots in the fine root fraction are very sensitive to drought stress. This study suggests that in the surviving fine root fraction, runner roots with secondary thickening as described by Sutton \& Tinus (1983) play a major role. This means that the situation is relatively favourable for a completely new system of fine roots to develop quickly when more moisture becomes available after rain, because roots with secondary thickening are capable of forming extra root tips during branching. Hence, the number of growing root tips can increase quickly under such circumstances.

Each year there were more fine roots in Kootwijk than in Speuld. The aboveground growth in Kootwijk is slower than in Speuld. Thus there were more fine roots at the site with the poorest soil quality. Keyes \& Grier (1981) also found larger amounts of fine root biomass in poorly productive sites. When the physical and chemical conditions of the soil are good, trees can take up enough water and nutrients with lower root densities. In combination with root density, the soil hydraulic conductivity plays an important role in the ability of root systems to take up water (de Willigen \& van Noordwijk, 1987). The unsaturated hydraulic conductivity is usually greater in soil with a larger loam or organic matter content.

Trees on very productive sites need a relatively large coarse root system to support the aboveground biomass and to guarantee transport capacity for water and 
nutrients. It seems logical for the coarse root fraction to be directly proportional to the aboveground biomass. In studies on the relationship between shoots and roots it is certainly appropriate to separate the fine and the coarse root fractions, even in seedling trials. The estimated weight of the coarse roots in these two Dutch Douglas fir plantations is 6 (Kootwijk) or 10 (Speuld) times the weight of the fine roots, even when fine root density is high. To analyze the functional equilibrium (Brouwer, 1983) between aboveground and belowground plant parts in woody plants, it is logical to only sample tissue that is in exchange with its environment: i.e. leaves and fine roots. The ratio of leaf area index (LAI) over root area index (RAI) would be a good indicator for the functional equilibrium between shoots and roots. The relative large weight of the supportive coarse roots makes it difficult to detect any shifts in belowground uptake capacity in relation to the assimilating leaf surface. If for example changes induced by atmospheric deposition of nitrogen are to be detected, careful attention should be paid to fine root density.

\section{Acknowledgements}

This project was supported by the Dutch Priority Programme on Acidification. Roots and data were processed by G. M. J. H. Ackermans, A. Verdoes, J. M. Klap, C. van der Haar, M. Stempher, W. de Bruijn, and W. H. K. Post. 'De Dorschkamp' Research Institute for Forestry and Urban Ecology offered facilities during the preparation of this paper. G. M. J. Mohren, W. G. Keltjens, R. Rabbinge, R. A. A. Oldeman and G. F. Weetman made valuable comments on the manuscript.

\section{References}

Böhm, W., 1979. Methods of studying root systems. Ecological Studies. Vol. 33. Springer Verlag, 188 pp.

Bowen, C. D., 1985. Roots as components of tree productivity. In: M. G. R. Cannell \& J. E. Jackson (Eds), Attributes of trees as crop plants. p. 303-315. Institute of Terrestrial Ecology, Abbotts Ripton, UK.

Brouwer, R., 1983. Functional equilibrium: sense or nonsense? Netherlands Journal of Agricultural Science 31: 335-348.

Eis, S., 1987. Root systems of older immature hemlock, cedar, and Douglas-fir. Canadian Journal of Forest Research 17: 1348-1354.

Evers, P., C. J. M. Konsten \& A. W. M. Vermetten, 1987. Acidification research on Douglas-fir forests the Netherlands (ACIFORN project). In: P. Mathy (Ed), Air pollution and ecosystems, p. 887. Reidel Publishing Company, Dordrecht, Netherlands.

FAO/UNESCO, 1974. Soil map of the world 1:5000 000. Vol. I. Legend. UNESCO, Paris, $59 \mathrm{pp.}$

Keyes, M. R. \& C. C. Grier, 1981. Above- and belowground net production in 40-year-old Douglas-fir stands on low and high productivity sites. Canadian Journal of Forest Research 11: 599-605.

Kuiper, L. C. \& M. P. Coutts, 1991. Spatial disposition and extension of the structural root system of Douglas-fir. Forest Ecology and Management (in press).

Kummerow, J., J. Castillanos, M. Maas \& A. Larigauderie, 1990. Production of fine roots and the seasonality of their growth in a Mexican deciduous dry forst. Vegetatio 90: 73-80.

McMinn, R. G., 1963. Characteristics of Douglas-fir root systems. Canadian Journal of Botany 41: 105122. 


\section{A. F. M. OLSTHOORN}

Noordwijk, M. van, J. Floris \& A. de Jager, 1985. Sampling schemes for estimating root density distribution in cropped fields. Netherlands Journal of Agricultural Science 33: 241-262.

Noordwijk, M. van, Widianto, M. Heinen \& Kurniatun Hairiah, 1991. Old tree root channels in acid soil in the humid tropics: important for crop root penetration, water infiltration and nitrogen management. In: R. J. Wright, V. C. Baligar \& R. P. Murrma (Eds), Utilization of acid soils for crop production. Kluwer Academic Publishers, Dordrecht, Netherlands.

Olsthoorn, A. F. M. \& A. Tiktak, 1991. Fine root density and root biomass of two Douglas-fir stands on sandy soils in the Netherlands. 2. Periodicity of fine root growth and estimation of belowground carbon allocation. Netherlands Journal of Agricultural Science 39: 61-77.

Reynolds, E. R. C., 1970. Root distribution and the cause of its spatial variability in Pseudotsuga taxifolia (Poir.) Britt. Plant and Soil 32: 501-517.

Santantonio, D. \& R. K. Herman, 1985. Standing crop, production, and turnover of fine roots on dry, moderate, and wet sites of mature Douglas-fir in western Oregon. Annales des Sciences Forestières 42: $113-142$.

Santantonio, D., R. K. Hermann \& W. S. Overton,1977. Root biomass studies in forest ecosystems. Pedobiologia 17: 1-31.

Sutton, R. F. \& R. W. Tinus, 1983. Root and root system terminology. Forest Science Monograph No 24: $137 \mathrm{pp}$. Supplement to Forest Science 29.

Tennant, D., 1975. A test of a modified line intersect method of estimating root length. Journal of Ecology 63: 995-1001.

Vogt, K. A., E. E. Moore, D. J. Vogt, M. J. Redlin \& R. L. Edmonds, 1983. Conifer fine root and mycorrhizal root biomass within the forest floors of Douglas-fir stands of different ages and site productivities. Canadian Journal of Forest Research 13: 429-437.

Vogt, K. A., R. L. Edmonds \& C. C. Grier, 1981. Seasonal changes in biomass and vertical distribution of mycorrhizal and fibrous-textured conifer fine roots in 23- and 180-year-old subalpine Abies amabilis stands. Canadian Journal of Forest Research 11: 223-229.

Willigen, P. de \& M. van Noordwijk, 1987. Roots, plant production and nutrient use efficiency. Doctoral Thesis, Wageningen Agricultural University, Netherlands, $282 \mathrm{pp}$. 